\title{
Pre- and postpartum effects of starch and fat in dairy cows: A review
}

\author{
B. A. Useni ${ }^{1 \#}$, C. J. C. Muller ${ }^{1,2} \&$ C. W. Cruywagen ${ }^{1}$ \\ ${ }^{1}$ Department of Animal Sciences, University of Stellenbosch, Private Bag X1, Matieland 7602, South Africa \\ ${ }^{2}$ Western Cape Department of Agriculture, Research and Technology Development Services, Directorate: Animal \\ Sciences, Private bag X1, Elsenburg 7607, South Africa
}

(Received 15 June 2017; Accepted 10 January 2018; First published online 30 January 2018)

\begin{abstract}
Copyright resides with the authors in terms of the Creative Commons Attribution 4.0 South African Licence.
See: http://creativecommons.org/licenses/by/4.0/za

Condition of use: The user may copy, distribute, transmit and adapt the work, but must recognise the authors and the South African Journal of Animal Science.
\end{abstract}

\begin{abstract}
This review discusses the effects of starch and fat before and after calving on metabolism, energy balance (EB), milk production, and reproduction in dairy cows. The shift in dairy cows from a pregnant nonlactating state to a non-pregnant lactating state induces physiological changes, which affect the metabolic and endocrinal axes to redirect body energy stores towards the mammary gland for milk production. Overfeeding high starch and fat levels during the dry period after calving may result in cows failing to adapt to the negative energy balance (NEB) because of major liver and rumen dysfunction. Alternatively, keeping dry cows on high-forage/low-energy diets adjusts dry matter intake (DMI) to optimize the rumen function and decrease the severity of the NEB during transition. These periparturient biological improvements in dairy cows showed real benefits such as fewer postpartum health complications (e.g. milk fever, ketosis, mastitis, metritis), decreased body condition loss and improved reproductive axis in the subsequent lactation. Adding dietary starch and/or fat to diets of dairy cows following parturition increased milk yield. In addition, milk protein of dairy cows increased with glucogenic diets, but decreased with lipogenic diets. Inversely, milk fat usually increases after feeding lipogenic diets, but it decreases when feeding glucogenic diets to dairy cows. Glucogenic and lipogenic nutrients can affect the cow's metabolism and its EB status positively, as is evidenced by plasma non-esterified fatty acids (NEFA), $\beta$-hydroxybutyrate (BHB), glucose, amino acids, insulin, insulin-like growth factor-I (IGF-I), growth hormone (GH), gonadotropin hormones, and progesterone $\left(\mathrm{P}_{4}\right)$ levels. These metabolites (NEFA, BHB, glucose, amino acids) and hormones (insulin, IGF-I, GH, $\mathrm{P}_{4}$ ) have been shown to affect folliculogenesis, ovulation, conception, and pregnancy success. Feeding a starchbased diet to dairy cows can lead to acidosis and increase glucose and insulin levels, while decreasing NEFA and BHB levels. Furthermore, an insulinogenic diet favours an early resumption of ovarian activity, but has adverse effects on the quality of oocytes. In contrast, keeping dairy cows on a fat-based diet elevates NEFA and BHB levels and decreases glucose and insulin levels. Additionally, a lipogenic diet increases the plasma $\mathrm{P}_{4}$ levels and improves the quality of oocytes. These evidences suggest that reproductive performances in dairy cows can be enhanced by feeding an insulinogenic diet until the resumption of the ovarian cycle then switching to a lipogenic diet from mating period onwards. Since long-term field studies on fertility are limited and the reproduction process in dairy cows is multi-factorial, further research is needed on the pre- and postpartum effects of starch and/or fat as well as their combinations on reproduction axis and thus to draw conclusions on reproductive performances.
\end{abstract}

Keywords: Digestion, energy nutrients, metabolism, milk production, reproduction, ruminant

\# Corresponding author: alainub83@gmail.com

\section{Introduction}

Carbohydrate and fat-based feedstuffs are major energy components that are usually used in the diets of dairy cows (Schroeder et al., 2004; Carmo et al., 2015). Glucogenic-based feedstuffs provide the fermentable energy and improve the protein/energy balance to potentially enhance the supply of rumen microbial protein synthesis (MPS) to the small intestine (Rearte \& Pieroni, 2001; Bargo et al., 2003). 
Glucogenic-based ingredients consist of cereal grains and their milling by-products, molasses, beet and citrus pulps, roots and tubers such as cassava and potatoes and their by-products, and dried reclaimed bakery products (McDonald et al., 2002; Mosavi et al., 2012; Steyn et al., 2017). Fat increases the energy density of the diet (Schroeder et al., 2004), and in particular enhances plasma cholesterol, the major precursor for steroidogenesis, including luteal $\mathrm{P}_{4}$ synthesis in postpartum cows (Roche et al., 2011). Fat can be included in the form of ruminally inert sources such as hydrogenated fish fat, high melting point fatty acids, and calcium $(\mathrm{Ca})$ salts of long-chain fatty acids or non-ruminally inert sources such as soybean oil and full fat rapeseed (Bargo et al., 2003). Manipulating the energy level and source in the diet of pre- and postpartum cows showed significant improvements in terms of decreased incidence of health problems (Beever, 2006), optimized rumen microbial activity (Jouany, 2006), increased amount of digested nutrients from the gastro-intestinal tract (GIT) (Bauman \& Currie, 1980), decreased body condition loss (Drehmann, 2000; Butler, 2003), and increased milk responses (Grum et al., 1996; Ingvartsen \& Andersen, 2000; Cavestany et al., 2009a; Reis et al., 2012; Damgaard et al., 2013; Roche et al., 2013; Hills et al., 2015). However, studies on the pre- and postpartum effects of starch- or fat-based diets on dairy cow reproduction parameters are contradictory, with some studies reporting a negative effect or lack of effect of it (Beam \& Butler, 1997; Oldick et al., 1997; Oldick et al., 1998; McNamara et al., 2003; Van Knegsel et al., 2007c; Dyck et al., 2011; Gilmore et al., 2011), compared with other studies that reported a positive effect (Gong et al., 2002; Cavestany et al., 2009b; Garnsworthy et al., 2009; Reis et al., 2012; Little et al., 2016; Thatcher, 2017). The objectives of this review are therefore to discuss the effects of energy-based diets containing starch and/or fat during the dry and postpartum periods on the subsequent metabolism, milk production and fertility of dairy cows.

\section{Energy sources during the dry period}

A lactation period of 305 days, followed by a dry period of 56 to 60 days, has been regarded as a strategic management system for most dairy farms since the 1950s (Bachman \& Schairer, 2003). The dry period is defined as a period of preparation, allowing body and conceptus growth in heifers and body restoration and conceptus growth in dry cows, in anticipation of the next lactation (NRC, 2001; Beever, 2006). Through homeorhetic controls, the imposition of pregnancy during this period favours the partition of specific nutrients (i.e. glucose and amino acids) not only for foetal growth (i.e. about $60 \%$ relative to the calf live weight at birth), but also for the growth of the foetal membranes, the gravid uterus, and the mammary gland (Bauman \& Currie, 1980). However, the feed intake of heifers and dry cows usually declines in the late dry period relative to their energy requirements (Grummer, 1995; Huzzey et al., 2007), triggering the beginning of the NEB (Butler, 2003). The decrease in prepartum DMI can be attributed to digestive, hormonal, physiological and immunological factors related to this period, and to the rapid growth of the foetus, which takes up the abdominal space, thereby decreasing the rumen volume (Jouany, 2006; Wankhade et al., 2017). Everitt (1964) reported that the foetus of a ruminant is more vulnerable than that of many other species to maternal undernutrition stresses, which impede normal foetal growth. Thus, maternal adaptations during late pregnancy partitioned the nutrients in heifers and dry cows that are required for their own maternal growth and replenishment of protein and energy reserves to meet the foetal requirements (Bauman \& Currie, 1980).

Several studies have investigated and reviewed the possible benefits of starch- and fat-based ingredients in prepartum diets of dairy cows (Grum et al., 1996; Drackley, 1999; Agenäs et al., 2003; McNamara et al., 2003; Dann et al., 2005; Janovick \& Drackley, 2010; Janovick et al., 2011; Damgaard et al., 2013). However, results are limited, and in some instances are conflicting, with certain studies showing a positive prepartum effect on EB status (Grum et al., 1996; Janovick \& Drackley, 2010; Janovick et al., 2011; Damgaard et al., 2013), milk yield (Ingvartsen \& Andersen, 2000; Cavestany et al., 2009a), milk composition (Cavestany et al., 2009b; Grum et al., 1996; Damgaard et al., 2013), and reproduction performance (Cavestany et al., 2009b), with others reporting the lack of effect on these traits (McNamara et al., 2003; Agenäs et al., 2003; Burke et al., 2010; Mann et al., 2015). Unrestricted feeding of a diet containing higher energy levels (starch or fat) to prepartum cows enhanced DMI, allowing them to consume too much energy relative to their nutritional requirements, compared with those being fed a lower energy density diet (Janovick \& Drackley, 2010). Overconsuming starch increased the osmolality of the rumen contents and inflamed the rumen epithelium, resulting further in hepatic fat deposition (Beever, 2006) and a greater decline in DMI (Minor et al., 1998; Olsson et al., 1998). Furthermore, feeding prepartum high starch diets increased the production of volatile fatty acids (VFAs) and resulted in a decrease in $\mathrm{pH}$ below 5.5 and an accumulation of lactic acid in the rumen. This decline in DMI and ruminal $\mathrm{pH}$ exacerbates the EB deficit in cows (Jouany, 2006). Alternatively, the overconsumption of fats results in inhibitory effects on microbial fermentation and sensitivity to nutrient imbalances in the rumen, causing reduced DMI (Palmquist, 1994). Additionally, feeding high prepartum levels of dietary fat negatively affected the EB status, as is evidenced by increased plasma 
NEFA and BHB levels and decreased insulin levels (Leroy et al., 2008b; Damgaard et al., 2013), which result in longer anoestrous periods in the subsequent lactation (Giuliodori et al., 2011). In both energy feeding contexts, dry cows can possibly fail to adapt to the NEB stress when fed high prepartum levels of starch and fat due to the associated metabolic and rumen dysfunctions (Jouany, 2006; Janovick et al., 2011; Mann et al., 2015). Furthermore, a severe NEB during the prepartum period has been associated in the subsequent lactation with increased health problems (e.g. retained placenta, ketosis, abomasum displacement, lameness, mastitis, and endometritis) (Duffield et al., 2009; Ospina et al., 2010a; McArt et al., 2012), reduced reproductive success, and decreased milk production (Duffield et al., 2009; Ospina et al., 2010b; 2010c).

The optimal prepartum dietary management strategy with reference to the types and levels of energy intake and control of DMI is still to be developed (Janovick \& Drackley, 2010). Some studies indicated that an overconsumption of energy prepartum is detrimental to postpartum cow health and liver function (Grum et al., 1996; Rukkwamsuk et al., 1999), whereas others demonstrated that supplementing extra energy during the dry period is beneficial to transition success (Dann et al., 1999; Rabelo et al., 2005). Consequently, recent studies investigated the potential benefits of feeding fibre-based diets containing $>400 \mathrm{~g} / \mathrm{kg}$ of NDF and low digestible energy levels on DM basis during the dry period (Janovick et al., 2011; et al., 2013; Mann et al., 2015). Such prepartum diets were reported to adjust the DMI, which optimized the rumen digestion and fermentation (Jouany, 2006) and decreased the mobilization of body reserves, as well as the deposition of lipid and tri-acyl glycerol (TAG) in the liver (Mann et al., 2015). Controlling the energy content in prepartum diets is usually achieved by adding bulky lower-quality forages such as chopped wheat straw or oat hay, which increase fibre content and limit the voluntary DMI (NRC, 2001), thereby regulating total nutrient consumption. Maintaining pregnant dry cows on high-forage/low-energy diets has shown significant improvements in their subsequent lactations in terms of fewer health problems (e.g. ketosis, abomasum displacement, and fatty liver syndrome), reduced body condition loss, and improved reproductive axis (Drehmann, 2000, Beever, 2006; Jouany, 2006). Thus, the evidence revealed that feeding a prepartum forage-based diet containing low digestible energy level optimized the GIT and rumen microbial activity (Jouany, 2006), improved metabolic status, and reduced the risks of ketosis and fatty liver syndrome in periparturient dairy cows (Janovick et al., 2011; Vickers et al., 2013; Mann et al., 2015). However, long-term feeding trials that investigated the prepartum effect of energy levels and sources and their combinations on the postpartum milk responses and reproductive performances of dairy cows are limited, making it difficult to draw final conclusions.

\section{Negative energy balance and postpartum-related disorders in dairy cows}

Over the past few decades, a significant increase in milk yield has been observed in dairy herds (Leroy et al., 2008b; 2008c; Roche et al., 2011) as a result of intense genetic selection, improved nutrition, and better cow management (Lucy, 2001; Thatcher et al., 2011). However, several studies have shown that the improvement in milk yield is associated with some negative consequences, such as increased occurrence of metabolic and infectious diseases and a decline in reproductive performance (Lucy, 2001; 2007; Butler, 2003; Walsh et al., 2011; Wathes, 2012; Thatcher et al., 2017). As indicators of reproduction management efficiency, the calving interval and the number of artificial inseminations (Als) per conception have increased substantially worldwide (Butler, 1998). In South African Holsteins for instance the intercalving period increased from 386 days in 1986 to 412 days in 2004 (Makgahlela, 2008).

During the transition period from a pregnant non-lactating state to a non-pregnant lactating state, dairy cows are confronted with numerous physiological challenges and stressors related to parturition and the onset of lactation (Evans \& Walsh, 2012; McArt et al., 2013; Esposito et al., 2014). One of the main challenges is a rapid rise in nutrient requirements (Ingvartsen, 2006), essentially doubling overnight once milk production begins (Drackley et al., 2005). In the week preceding calving, the cow's appetite decreases (Walsh et al., 2011) and the DMI has been reported to decline by approximately $30 \%$, occurring within 24 hours before calving (Huzzey et al., 2007). Thus, cows enter into a NEB status and mobilize stored triglycerides from adipose tissues in an attempt to meet the energy requirements (Rukkwamsuk et al., 1999). The NEB starts a few days before calving until 70 to 84 days post partum, coinciding with the beginning the breeding season (Butler, 2003; Roche et al., 2009). The NEB impairs the general metabolic system in dairy cows and has been identified by a number of researchers (Butler \& Smith, 1989; Garnsworthy \& Webb, 1999; Butler, 2003; Jorritisma et al., 2003) as an underlying causal factor of poor lifetime milk production and reproductive performance

Several reviews have been published regarding the effect of the EB status on reproductive efficiency of dairy cattle (Beam \& Butler, 1999; Butler, 2000; 2003; Jorritisma et al., 2003; Van Knegsel et al., 2005; Wathes et al., 2007; Santos et al., 2008; Roche et al., 2011; Evans \& Walsh, 2012; Leroy et al., 2014). The status of NEB alters the insulin level and the GH-IGF-I axis to decrease the bioavailability of circulating IGF-I (Wathes et al., 2007). Furthermore, it decreases the luteinizing hormone (LH) pulse frequency, the diameter 
and growth rate of the dominant follicle, the activity of the corpus luteum, and perioestrous hormone levels such as oestradiol and $\mathrm{P}_{4}$ (Beam \& Butler, 1997; 1999; Butler, 2000). The effects of these EB-induced alterations on fertility have resulted in increased number of days from calving to the resumption of oestrus and days open and to decreased conception rates following fertilization and pregnancy survivals afterwards (Giuliodori et al., 2011; Roche et al., 2011).

When dairy cows experience a NEB, their immune system is likely to be compromised (Mallard et al., 1998; Wankhade et al., 2017). The level of impairment and the degree of reclamation of postpartum immune competence are influenced strongly by the extent and duration of the NEB around calving (Pyörälä, 2008; Wathes et al., 2009), making cows in a severe NEB more vulnerable to infections caused by pathogenic organisms (Goff, 2006; Wathes, 2012). Gröhn et al. (1995) studied the prevalence of postpartum diseases in multiparous cows in 25 Holstein herds in North America and found $7.4 \%$ incidence of retained placenta, $7.6 \%$ incidence of metritis and $4.9 \%$ incidence of ketosis. Jordan \& Fourdraine (1993) surveyed 61 top milkproducing herds in North America and reported 3.7\% incidence of ketosis, $9.0 \%$ incidence of retained placenta and $12.8 \%$ incidence of metritis. Other reports found that the effects of metabolic biomarkers (i.e. high NEFA and BHB) due to poor adaptation of lactating cows to the energy stress were associated with the occurrence of abomasum displacement, clinical ketosis, lameness, mastitis, and endometritis, which all can contribute to an increased risk of culling of affected animals (Seifi et al., 2011; Walsh et al., 2011; Evans \& Walsh, 2012; Esposito et al., 2014). Metabolic and infectious diseases can lead to lower milk yields (RajalaSchultz et al., 1999a; 1999b), lower conception rates (LeBlanc et al., 2002; Hansen et al., 2004; Bisinotto et al., 2012), and increased incidences of involuntary culling (Gröhn et al., 1998; Esposito et al., 2014).

\section{Energy partitioning in dairy cows}

Feed constituents such as dietary fibre, starch and protein provide substrates for rumen microbial fermentation, which yields gases (with the main ones being methane or $\mathrm{CH}_{4}$, carbon dioxide or $\mathrm{CO}_{2}$ and hydrogen or $\mathrm{H}_{2}$ ), MPS, and VFA. Rumen VFAs provide energy in dairy cows and the main ones are acetate, butyrate, and propionate. Fat is hydrolysed into fatty acids and hydrogenated in the rumen. Ruminal bypass nutrients and microbial matter can be digested and absorbed in the small intestine, providing additional glucogenic and lipogenic as well as amino acid compounds to the animal (McDonald et al., 2002). These absorbed nutrients proceed in the liver through a succession of pathway reactions of the Krebs cycle involving oxygen (respiratory chain reactions) to produce the body energy fuel as adenosine triphosphate (Van Knegsel et al., 2005).

As parturition occurs and dairy cows shift into producing milk, the requirement for nutrients increases because of the onset of lactation and also of the initial depression of DMI around parturition (Walsh et al., 2011; Evans \& Walsh, 2012). Requirements for glucose and metabolizable energy (ME) increase by two- to threefold after the onset of the lactation (Drackley et al., 2001). Also, an increase occurs in postpartum plasma GH levels, thus prioritizing high milk synthesis in the mammary gland (Chagas et al., 2007). In the liver, the improvement in plasma GH levels directly stimulates gluconeogenesis and indirectly antagonises the production of insulin, necessary for meeting the glucose demands for milk production (Lucy, 2004). As a result of low plasma glucose and insulin levels, body fat and, to a lesser degree, body protein stored as body reserves are mobilized (Van Knegsel et al., 2005), usually through homeostatic regulation (Roche et al., 2009; Thatcher et al., 2011). This mobilization results in a loss of body condition score and live weight (Jorritsma et al., 2003; Van Straten et al., 2008) as a physiological mechanism to overcome the energy deficit. Non-esterified fatty acids are consequently released from body fat reserves, with increasing NEFA levels in the bloodstream, suggesting an EB shortfall (Duffield, 2000; Wathes et al., 2007). The NEFA metabolites are directed into the mammary gland to supply milk triglycerides (Drackley, 2000) or utilized in the liver (Drackley et al., 2001; Vernon, 2002; Schulz et al., 2014). Following their uptake by the liver, NEFA can be utilized in three pathways. First, NEFA can be oxidized to carbon dioxide to supply energy as alternative energy fuel for other tissues, while most of the glucose is diverted for lactose synthesis in the mammary gland (Vernon, 2002). Second, it can be partially oxidized to produce ketone bodies, acetone, aceto-acetate and BHB, which may result in ketosis (Schulz et al., 2014; Esposito et al., 2014). Third, it may be esterified to triglycerides or phospholipids and stored in the liver as TAG, with the possibility of causing fatty liver syndrome (Drackley et al., 2001). This mobilization highlights that the metabolic effects of a NEB status in early lactation induce an imbalance in the ratio of plasma glucogenic and lipogenic compounds derived from feed nutrients and body reserves (Schulz et al., 2014). Hence, the physiological consequences of postpartum EB deficit causes low plasma glucose and insulin levels associated with high levels of plasma NEFA, BHB, acetone, acetoacetate, and liver TAG (Van Knegsel et al., 2005; Evans \& Walsh, 2012). As lactating cows enter a state of NEB, physiologically they direct the limited available nutrients in their system to milk synthesis for the survival of living offspring. This prioritization occurs at the expense of the reproductive axis, thus limiting the dominant follicle to ovulate, be fertilized and cared for during an entire 
gestation (Leroy et al., 2008a). From this brief review, it appears that the brain, GIT, body reverses, foetus (before calving), and the udder, as well as the reproductive organ (after calving), are all components in the adaptation to EB status in dairy cows. In addition, the liver obviously plays a key role in coordinating metabolic responses in dairy cows in order to adapt and recover from NEB.

Several studies have indicated that dietary energy sources can be manipulated through inclusion of feedstuffs in the diet to prevent and/or treat NEB-related disorders (Staples et al., 1998; Gong et al., 2002; Jorritisma et al., 2003; Van Knegsel et al., 2005; 2007a; 2007b; 2007c; 2007d; Gilmore et al., 2011; Thatcher et al., 2011). McGuire et al. (2004) reported that the improvement in DMI is the critical factor in dairy cows in meeting the energy needs for greater amounts of milk produced in early lactation without a more prolonged period of NEB. In addition, increasing levels of glucogenic or lipogenic dietary components in a diet of dairy cows change plasma energy biomarkers to reduce adverse metabolic and infectious disorders and improve milk synthesis and reproductive function. Lipogenic ingredients that stimulate the production of butyrate and acetate in the rumen are expected to increase the ratio of plasma lipogenic/glucogenic compounds (Van Knegsel et al., 2005). In addition, feeding dietary fat results in increased energy partition into milk and consequently limits the energy partition into body reserves (Van Knegsel et al., 2007a). In contrast, glucogenic nutrients (grains, cassava and potatoes and their by-products) are either fermented in the rumen to stimulate the production of propionate or bypass the rumen and are absorbed in the small intestine as glucose. Consequently, glucogenic nutrients can increase insulin and glucose levels, thus decreasing the ratio of plasma lipogenic/glucogenic compounds (Van Knegsel et al., 2005). As a result of improved insulin and glucose levels, dietary starch stimulates body fat deposition and energy partitioning into body tissue (Van Knegsel et al., 2007a). When dairy cows are fed a starch- or fat-based diet in excess of their daily nutritional requirements, as milk production begins to decline in the final third of the lactating period, they regain a positive EB. At this time, the EB recovery, as evidenced by an increase in plasma insulin and glucose levels, allows the stimulation of the enzyme acetyl-CoA carboxylase in the liver (Drackley, 2000). This hepatic enzymatic activation promotes the restoration of body fat through lipogenesis (Bauman \& Currie, 1980) in anticipation of the next lactation (Friggens, 2003).

\section{Effect of energy sources on metabolism of dairy cows}

Cereal grains, such as maize, are fed primarily to provide energy to dairy cows and most of the digestible energy in cereal grains comes from starch (Ali et al., 2012). Levels of starch can range up to $30 \%$ on a DM basis of the diet in lactating dairy cows (Akins et al. 2014). Most of the starch is hydrolysed by various routes to pyruvic acid, which is then fermented in the rumen. The ruminal fermentation process increases the production of VFAs and greenhouse gases $\left(\mathrm{CH}_{4}, \mathrm{CO}_{2}\right.$ and $\left.\mathrm{H}_{2}\right)$. The VFAs and greenhouse gases are absorbed through the rumen wall and lost by eructation, respectively. Starch also affects the protein/energy balance and the rumen MPS in ruminants (Rearte \& Pieroni, 2001; Bargo et al., 2003). The rest of the starch, bypassing rumen fermentation, is digested by pancreatic enzymes and absorbed in the small intestine as glucose (Norberg et al., 2007). In dairy cows, the addition of starch to the diet decreases the energy loss through energy sparing from gluconeogenesis and results in a decrease in $\mathrm{CH}_{4}$ production per unit of product through the increase in the efficiency of animal production (McDonald et al., 2002). Furthermore, dietary starch is efficient in alleviating the NEB, suggesting a reduced postpartum risk of metabolic disorders (Van Knegsel et al., 2007c). However, feeding high levels of starch can increase the risk of ruminal acidosis, diminish ruminal fibre digestibility, reduce the ruminal acetate/propionate ratio, and decrease the synthesis of milk fat in the udder (Bargo et al., 2003).

Dietary fat improves the energy density of the diet and increases the synthesis of milk fat in the mammary glands of dairy cows (Schroeder et al., 2004). It is almost entirely hydrolysed into fatty acids and hydrogenated in the rumen and subsequently absorbed from the small intestine (Doreau \& Ferlay, 1994). Adding more than $8-9 \%$ of fat to the diet may result in milk fat and milk protein depression in the udder owing to its negative effect on DMI and rumen fermentation of fibre in particular (Schroeder et al., 2004). To overcome these complications and to improve the energy intake, interest has increased in feeding ruminally inert fats, such as Ca-salts of long-chain fatty acids, to lactating dairy cows (Schneider et al., 1988). The Casalts of long-chain fatty acids are energetically dense and consist of about $51.6 \%$ palmitic acid, $5.9 \%$ stearic acid, $35.4 \%$ oleic acid, and $6.2 \%$ linoleic acid (Schneider et al., 1988). In the rumen, these fats are insoluble and inert at ruminal $\mathrm{pH}$ variations (Chalupa et al., 1986) and decrease $\mathrm{CH}_{4}$ production per DMI without any decrease in digestibility (Holter \& Young, 1992). In the abomasum, the fats are broken down by hydrochloric acid to free fatty acids and $\mathrm{Ca}$-ions. The rumen bypass of these fats consequently increases their absorption from the small intestine, potentially enhancing the supply of polyunsaturated fatty acids to the mammary gland (Purushothaman et al., 2008). Such synthesis of milk with modified fat composition has been associated with decreased risk of chronic diseases, including heart disease in humans (Lock \& Bauman, 2004). 
The inclusions of dietary starch and fat into diets of dairy cows have been demonstrated to be effective in reducing the extent and duration of NEB during early lactation (Williams \& Stanko, 2000; Van Knegsel et al., 2007c; Garnsworthy et al., 2009). As nutrients are digested and absorbed through the GIT, a number of metabolic and hormonal signals released from the liver, pancreas, muscle and adipose tissues act on brain centres, regulating the DMI, EB and metabolism of dairy cows (Chagas et al., 2007). The signals, which can include glucose, fatty acids, insulin, IGF-I, glucagon, GH, ghrelin, leptin, and perhaps myostatin, trigger their receptors by means of positive and negative endocrinal feedback mechanisms to regulate DMI, body growth and reserves, milk synthesis and the reproductive axis (Chagas et al., 2007; Lucy, 2007; Garnsworthy et al., 2008a; Roche et al., 2009; Wathes, 2012; Esposito et al., 2014; Wankhade et al., 2017). At the ovarian level, the reproductive axis is regulated by the hormones of the hypothalamus (gonadotropin-releasing hormone $(\mathrm{GnRH})$ ), anterior pituitary (follicle-stimulating hormone $(\mathrm{FSH})$ and $\mathrm{LH})$, ovaries $\left(\mathrm{P}_{4}\right.$, oestradiol and inhibins), and the uterus (prostaglandin- $\mathrm{F}_{2 \alpha}\left(\mathrm{PGF}_{2 \alpha}\right)$ ) through a system of positive and negative feedback signals governing the oestrous cycle in dairy cows (Forde et al., 2011). The ovarian follicular growth and development are characterized by consecutive follicular waves, that is, three in dairy cows and two in heifers per oestrous cycle. Each wave begins with the recruitment of a cohort of follicles from the established fixed number of primordial follicles during foetal development and finishes with the selection of a dominant follicle (Webb et al., 2004). While other recruited follicles undergo atresia, the dominant follicle continues to grow and mature in the preovulatory stage and eventually ovulates. When cows are in a NEB condition, NEFA and $\mathrm{BHB}$ are released from body reserves and used as an alternative energy fuel for other tissues (Vernon, 2002; Esposito et al., 2014; Schulz et al., 2014). Second, the somatotropic axis (consisting of GH, GH receptor and IGF-I) becomes uncoupled in the liver (Thatcher et al., 2010). Third, less ghrelin is released from the abomasum and more GH from the anterior pituitary gland (Chagas et al., 2007). Furthermore, less insulin, IGF-I and leptin are released from the pancreas, liver and adipose tissue, respectively (Leroy et al., 2008b). Lastly, these altered endocrinal signals further attenuate the LH pulse frequency and decrease the production of $\mathrm{GnRH}$ (Butler, 2003) and therefore suppress altogether the reproductive axis (Chagas et al., 2007). Such metabolic and hormonal depressions, as dictated by the degree and duration of the NEB, influence the ovarian function negatively in terms of the number of follicles, the rate of follicular growth and development, the size of the ovulatory follicle and the quality and viability of the oocyte (Lucy et al., 1991; Boland et al., 2001; Butler, 2003; Diskin et al., 2003; Lucy, 2003; Webb et al., 2004; Garnsworthy et al., 2008a). In contrast, improvements in these feedback-regulated metabolites (e.g. glucose, amino acids, fatty acids) and hormones (e.g. insulin, IGF-I and leptin) regulate the hypothalamic-pituitary-ovarian-uterine axis positively to enhance fertility outcomes of dairy cows (Leroy et al., 2008a; 2008b; 2008c).

Feeding diets that are designed to increase insulin levels during early lactation may increase the proportion of cows ovulating before 50 days' post partum (Gong et al., 2002; Van Knegsel et al., 2005). Adding dietary starch to the diets of dairy cows can improve insulin and glucose levels (Lammoglia et al., 1997) and reduce NEFA and BHB levels during the NEB period (Van Knegsel et al., 2007b) to eventually promote the resumption of the oestrous cycle (Garnsworthy et al., 2008b). However, high starch diets may suppress the appetite and thus DMI by inducing satiety and shorter meals (Thatcher et al., 2011). Furthermore, excessive insulin and IGF-I levels from high starch diets may overstimulate the ovary to negatively affect the developmental competence of oocytes (Leroy et al., 2008c). This overstimulation results in the production of inferior oocytes owing to uncoupled transcriptional factors (i.e. maternal messenger RNA and protein molecules) in the dominant follicle to acquire the full competence before ovulation (Armstrong et al., 2001). Poor transcription of these factors significantly reduces the quality and viability of the oocyte and after fertilization decreases the survival of the embryo prior to embryonic genome activation, which occurs at the 8-16 cell stage (Leroy et al., 2008b; 2008c). In contrast, the inclusion of dietary fat in a diet of dairy cows enhances the diet energy density stimulating milk synthesis, and yields higher NEFA and BHB levels associated with lower glucose and insulin levels (McNamara et al., 2003; Van Knegsel et al., 2005, 2007b; Moallem et al., 2007). Furthermore, feeding dietary fat increases the number and size of follicles, and the oestradiol production of the preovulatory follicle (Lucy et al. 1991; Beam \& Butler, 1997; Moallem et al., 2007), most likely via the induction of high cholesterol and IGF-I levels in follicular fluid and plasma (Van Knegsel et al., 2007a; Esposito et al., 2012). Vasconcelos et al. (2001) reported that an increased follicle size can have advantageous effects on both oocyte quality and corpus luteum function. The resulting high plasma cholesterol concentration improves $\mathrm{PGF}_{2 \alpha}$ and $\mathrm{P}_{4}$ secretion (Staples et al., 1998; Staples \& Thatcher, 2005; Leroy et al., 2014), thus supporting embryo development and pregnancy survival (Ryan et al., 1992; Lammoglia et al., 1996; McNamara et al., 2003).

Obviously, manipulating the levels and types of energy feedstuffs containing dietary starch and fat can be a key tool in decreasing energy metabolic loss and optimizing the EB status of dairy cattle, while enhancing metabolic efficiency. This indicates that feeding starch- and fat-based diets to dairy cows can increase productivity and thus reduce $\mathrm{CH}_{4}$ emissions per unit of production. However, a number of hormonal 
and metabolic signals are involved for successful reproduction of heifers and lactating cows, making physiological pathways with many inter-related factors complex (Chagas et al., 2007; Garnsworthy et al., 2008a).

\section{Effect of energy sources on milk yield and milk composition}

Increasing fat- and starch-based ingredients in the daily diet raised the milk production of dairy cows (Van Knegsel et al., 2005; Reis et al., 2012; Higgs et al., 2013; Roche et al., 2013). A possible explanation for the improved milk production can be attributed to the amount of energy intake, increasing the ME intake with both starch and fat ingredients (Bargo et al., 2003; Hills et al., 2015). Such an enhancement in ME intake was reported to affect lactation persistence positively (Hermansen, 1990; Reis et al., 2012). Supporting this response, previous studies reported enhanced milk production as a result of increased energy intake (Erickson et al., 1992; Chouinard et al., 1997; Moallem et al., 2000). However, other studies reported no effect on milk yield when feeding enriched starch- or fat-based diets or combinations (Garnsworthy et al., 2008b; 2008c; 2009; Gilmore et al., 2011; Little et al., 2016). These researchers suggested that the lack of a significant effect on milk production could be attributed to the use of isocaloric diets in the studies.

Milk lactose percentage of dairy cows increased with the inclusion of dietary starch, but decreased with the addition of dietary fat (Van Knegsel et al., 2007c). However, other studies reported no effect on milk lactose percentage when starch or fat was added to diets of dairy cows (Van Knegsel et al., 2007a; Garnsworthy et al., 2008b; 2008c; 2009). The reason for these differences may be related to a limited capacity of the mammary gland to absorb increased glucose from the blood or to low plasma glucose available for lactose synthesis during early lactation (Piccioli-Cappelli et al., 2014). Milk protein percentage of dairy cows decreased with lipogenic diets (Erickson et al., 1992; Harrison et al., 1995; Chouinard et al., 1997). This inverse effect may be explained by the limitation in rumen microbial synthesis and gluconeogenesis with fats, leading to poor protein synthesis in the udder (Palmquist, 1988). However, glucogenic diets increased the milk protein percentage of dairy cows (Voigt et al., 2003), which may be attributed to greater plasma insulin levels (McGuire et al., 1995; Van Knegsel et al., 2007b), an enhanced MPS in the rumen (Carmo et al., 2015) and a greater mammary protein synthesis (Hills et al., 2015).

Milk fat percentage was usually enhanced after feeding lipogenic diets, but decreased when feeding glucogenic diets to dairy cows (Van Knegsel et al., 2007a; 2007b; Garnsworthy et al., 2008b; 2008c; Reis et al., 2012). However, overfeeding dietary starch or fat to lactating cows could lead to a depression in milk fat yield. Van Knegsel et al. (2007b) reported that an increase in insulin levels, induced by increased propionate from rumen digestion of starch, can promote glucogenesis over lipogenesis owing to low availability of fat precursors, to subsequently reduce the fat synthesis in the udder and milk energy output. Another report argued that the depression in milk fat content is possibly caused by an accumulation of trans fatty acids in the rumen because of the low pH with high starch diets (Kalscheur et al., 1997). Bauman \& Griinari (2001) found that the decrease in milk fat content when overfeeding fat is generally attributed to altered rumen function, fat biohydrogenation and ruminal formation of trans-10 C18:1 fatty acids. Gama et al. (2008) pointed out that an increased supply of trans-10 cis-12 conjugated linoleic acid over other fatty acids to the udder was responsible for milk fat depression in dairy cows. This fatty acid has been recognized as a possible inhibitor of milk fat synthesis, decreasing the activity of lipogenic enzymes in the mammary gland (Baumgard et al., 2002).

\section{Effect of energy sources on reproductive efficiency of dairy cows}

Successful reproduction in dairy heifers and cows is the consequence of a chain of events, which consists of the establishment of oestrus in heifers and resumption of postpartum oestrous function in cows, the development and ovulation of a viable oocyte, conception, embryo development, implantation in the uterus, maintenance of pregnancy, and eventually calving (Garnsworthy et al., 2008a). A disturbance at any of these steps results in the failure of a successful conception and embryonic/pregnancy survival (Leroy et al., 2008a; 2008b). Because of this, the fertility of dairy cows is defined as a multi-factorial trait (Butler, 2003). The general decline in fertility has been attributed to a network of genetic, environmental, and managerial factors and their interactions, making it difficult to determine the exact reason for the deterioration in cow fertility (Walsh et al., 2011). So, for example, a decline in the fertility of dairy cows has transpired to reduced ability of the uterus to recover after calving, longer anovulatory periods and behavioural anoestrus, poor oestrous signs, irregular oestrous cyclicity, poor oocyte quality, poor fertilization, abnormal embryonic implantation and foetus development, uterine/placental incompetence, and pregnancy loss (Mwaanga \& Janowski, 2000; Lucy, 2007; Wathes et al., 2007; Leroy et al., 2008c; Evans \& Walsh, 2012).

Endocrine status, the interval from calving to first oestrus, conception rate, and pregnancy maintenance are all altered when reduced DMI and longer periods of NEB are manifested in cows (Mwaanga 
\& Janowski, 2000). Increasing the amount of dietary starch and fat in the diet reduced the interval from calving to first ovulation and therefore initiated earlier postpartum cyclicity in cattle (Lammoglia et al., 1996; Gong et al., 2002; Santos et al., 2008; Burke et al., 2010). The early resumption of oestrous activity can be attributed to the improved EB status as the somatotropic axis synergises with the gonadotropins on ovarian cells, allowing the dominant follicle to ovulate and resuming the oestrous cycles afterwards. However, other studies reported no or negative effects of the energy intake level on the number of days from calving until the first oestrus (Beam \& Butler, 1997; 1998; Garcia-Bojalil et al., 1998; Oldick et al., 1997; Garnsworthy et al., 2009). Gong et al. (2002) reported increased conception rates following the first insemination when feeding dietary starch. In contrast, other investigations found no or negative effects of the energy intake level on the conception rate following the first insemination (McNamara et al., 2003; Garnsworthy et al., 2009; Gilmore et al., 2011). Furthermore, some studies found improved pregnancy rates when feeding dietary starch or fat to dairy cows (Burke et al., 2010; Reis et al., 2012), while others reported no or negative effects (McNamara et al., 2003; Dyck et al., 2011; Gilmore et al., 2011). However, important enhancements in conception rates were observed when feeding a diet that increased glucose and insulin levels in the early postpartum period and then switching to a diet that reduced insulin levels during the mating period, compared with other treatments (Garnsworthy et al., 2009). Furthermore, pregnancy rates for first and second services were enhanced when grass silage was supplemented with a similar concentrate fed to cows individually, based on the milk yield of the previous week, compared with those on a mixed diet containing grass silage and concentrate in a 50/50 ratio on a DM basis (Little et al., 2016). In contrast, Gilmore et al. (2011) found no improvements in pregnancy rates when feeding a glucogenic diet in early lactation to encourage the resumption of oestrus followed by a lipogenic diet to promote embryonic development, compared with other treatments. These researchers suggested that the lack of significance was due to the small number of animals used in the study.

Several causes could contribute to the inconsistency in effects of dietary starch and fat on the reproduction performance of dairy cattle in previous studies. First, the levels and types of dietary fat (chain length and degree of saturation of long-chain fatty acids) and starch (rate of fermentation in the rumen and proportion of rumen bypass starch) directly affected the profile of nutrients absorbed through the GIT and indirectly acted on the EB status, both of which probably influenced the ability to conceive and remain pregnant (Staples et al., 1998; Van Knegsel et al., 2007a; Leroy et al., 2008c; Roche et al., 2011). Second, it is critical to distinguish between non-isocaloric and isocaloric diets in studies, since the energy density, defined by the nutrient content (starch versus fat), has been described as having significant effects on reproductive efficiency (Van Knegsel et al., 2005). Another source of variation could be differences in numbers of animals, protocols and interpretations of experimental results among studies (McNamara et al., 2003; Gilmore et al., 2011).

Usually, feeding dietary starch that promotes glucose and insulin levels (Garnsworthy et al., 2008b) favours an early resumption of the first postpartum ovulation (Gong et al., 2002), while decreasing the quality of oocytes (Armstrong et al., 2001) and the conception rate (Leroy et al., 2008b). Plasma NEFA and BHB levels are increased and insulin levels are decreased with dietary fat inclusion (Leroy et al., 2008c), resulting in a longer anoestrous period (Giuliodori et al., 2011). However, dietary fat improves the quality of oocytes and corpus luteum (Beam \& Butler, 1997; Vasconcelos et al., 2001), while increasing the $P_{4}$ levels to enhance the pregnancy success (Roche et al., 2011). These results support the possible existence of nutritional signals associated with dietary energy levels and sources, dependently or independently of EB, which influence the reproduction axis through signals to the hypothalamus, pituitary, ovarian, oviductal, and uterine organs (Wathes et al., 2007). These observations suggest that the nutrient requirements for early resumption of ovarian cycles, follicle development and embryo development may be quite different in dairy cows, reflecting a potential advantage in diet alteration to ensure successful reproduction. This modification consists of feeding a glucogenic diet in early lactation to improve insulin levels for the resumption of oestrous activity, followed by a lipogenic diet before the breeding period to enhance cholesterol levels for oocyte quality and conceptus development. This feeding strategy has shown improved reproductive performance by feeding insulinogenic and lipogenic diets at different stages of the reproductive cycle (Garnsworthy et al., 2009). Despite all the progress made in this field, the physiological pathways explaining the link between EB indicators, hormonal and metabolic signals and their receptors, and pregnancy success remain, to a certain extent, unclear (Chagas et al., 2007). Additionally, feeding trials that investigated the interactions of energy levels and sources and their combinations from calving to mid or late lactation on reproductive performances are limited, thus making it difficult to draw final conclusions.

\section{Conclusion}

Inclusion levels and types of dietary energy sources, such as starch and fat, affect plasma metabolite profiles, milk production and fertility of dairy cows. Nutritional management before and after calving must 
facilitate successful metabolic adaptations in the liver and rapid increases of postpartum DMI, indispensable for improved milk production and efficient reproductive performance. This review demonstrated that there are definite physiological and metabolic links between the amounts and types of dietary energy nutrients absorbed through the GIT of dairy cows and their biological responses such as milk secretion and reproduction outcomes. In particular, relationships between metabolic (e.g. glucose, amino acids, fatty acids) and endocrinal (e.g. GH, insulin, IGF-I and leptin) signals and the reproductive system vary according to stage of the reproductive cycle. This suggest that the pregnancy rate could be optimized without compromising milk production with a two-diet strategy, consisting of a glucogenic diet until the resumption of the oestrous cycle and a lipogenic diet from the breeding period onwards. However, fertility before the establishment of oestrus in heifers or the resumption of oestrus in postpartum cows to the next calving is not only complex and multifactorial, but is in decline worldwide. In addition, bovine results on pre- and postpartum effects of energy sources and levels and their combinations on milk production and reproduction are limited under long-term field conditions. This is an area of research that requires detailed investigations.

\section{Acknowledgements}

The authors express gratitude to the Western Cape Department of Agriculture (WCDA) for permission to use the facilities and data towards a PhD study for Mr Useni at the University of Stellenbosch. The support of the workers and management at the dairy section of the Elsenburg Research Farm is also greatly appreciated. This study was funded by the Western Cape Agricultural Research Trust (WCART) with technical support by the WCDA. Mr Useni acknowledges the financial support from the WCART towards his PhD studies.

\section{Authors' Contributions}

Drafting of paper: BAU; critical revision: CJCM; final approval of version to be published: CWC.

\section{Conflict of Interest Declaration}

The authors certify that they have no affiliations with any organization or entity with financial or non-financial interest in the subject matter or materials discussed in this manuscript.

\section{References}

Agenäs, S., Burstedt, E. \& Holtenius, K., 2003. Effects of feeding intensity during the dry period: 1. Feed intake, body weight and milk production. J. Dairy Sci. 86, 870-882.

Akins, M.S., Perfield, K.L., Green, H.B., Bertics, S.J. \& Shaver, R.D., 2014. Effect of monensin in lactating dairy cows diets at 2 starch concentrations. J. Dairy Sci. 97, 917-929.

Ali, M., Weisbjerg, M.R., Cone, J.W., Van Duinkerken, G., Blok, M.C., Bruinenberg, M. \& Hendriks, W.H., 2012. Postruminal degradation of crude protein, neutral detergent fibre and starch of maize and grass silages in dairy cows. Anim. Feed Sci. Technol. 177, 172-179.

Armstrong, D.G., McEvoy, T.G., Baxter, G., Robinson, J.J., Hogg, C.O., Woad, K.J., Webb, R. \& Sinclair, K.D., 2001. Effect of dietary energy and protein on bovine follicular dynamics and embryo production in vitro: Associations with the ovarian insulin-like growth factor system. Biol. Reprod. 64, 1624-1632.

Bachman, K.C. \& Schairer, M.L., 2003. Invited review: Bovine studies on optimal lengths of dry periods. J. Dairy Sci. 86, 3027-3037.

Bargo, F., Muller, L.D., Kolver, E.S. \& Delahoy, J.E., 2003. Invited review: Production and digestion of supplemented dairy cows on pasture. J. Dairy Sci. 86, 1-42.

Bauman, D.E. \& Griinari, J.M., 2001. Regulation and nutritional manipulation of milk fat: Low-fat milk syndrome. Livest. Prod. Sci. 70, 15-29.

Bauman D.E. \& Currie, W.B., 1980. Partitioning of nutrients during pregnancy and lactation: A review of mechanisms involving homeostasis and homeorhesis. J. Dairy Sci. 63, 1514-1529.

Baumgard, L.H., Matitashvili, E., Corl, B.A., Dwyer, D.A. \& Bauman, D.E., 2002. Trans-10, cis-12 conjugated linoleic acid decreases lipogenic rates and expression of genes involved in milk lipid synthesis in dairy cows. J. Dairy Sci. 85, 2155-2163.

Beam, S.W. \& Butler, W.R., 1997. Energy balance and ovarian follicle development prior to first ovulation postpartum in dairy cows receiving three levels of dietary fat. Biol. Reprod. 56, 133-142.

Beam, S.W. \& Butler, W.R., 1998. Energy balance, metabolic hormones and early postpartum follicular development in dairy cows fed prilled lipid. J. Dairy Sci. 81, 121-131.

Beam, S.W. \& Butler, W.R., 1999. Effects of energy balance on follicular development and first ovulation in postpartum dairy cows. J. Reprod. Fertil. 54, 411-424.

Beever, D.E., 2006. The impact of controlled nutrition during the dry period on dairy cow health, fertility and performance. Anim. Reprod. Sci. 96, 212-226.

Bisinotto, R.S., Greco, L.F., Ribeiro, E.S., Martinez, N., Lima, F.S., Staples, C.R., Thatcher, W.W. \& Santos, J.E.P., 2012. Influences of nutrition and metabolism on fertility of dairy cows. Anim. Reprod. 9, 260-272.

Boland, M.P., Lonergan, P. \& O'Callaghan, D., 2001. Effect of nutrition on endocrine parameters, ovarian physiology and oocyte and embryo development. Theriogenology 55, 1323-1340. 
Burke, C.R., Kay, J.K., Phyn, C.V.C., Meier, S., Lee, J.M. \& Roche, J.R., 2010. Short communication: Effects of dietary non-structural carbohydrates prepartum and postpartum on reproduction of grazing dairy cows. J. Dairy Sci. 93 , $4292-4296$.

Butler, W.R., 1998. Review: Effect of protein nutrition on ovarian and uterine physiology in dairy cattle. J. Dairy Sci. 81, 2533-2539

Butler, W.R., 2000. Nutritional interactions with reproductive performance in dairy cattle. Anim. Reprod. Sci. 60-61, 449457.

Butler, W.R., 2003. Energy balance relationships with follicular development, ovulation and fertility in postpartum dairy cows. Livest. Prod. Sci. 83, 211-218.

Butler, W.R. \& Smith, R.D., 1989. Interrelationships between energy balance and postpartum reproductive function in dairy cattle. J. Dairy Sci. 72, 767-783.

Carmo, C.A., Batistel, F., De Souza, F., Martinez, J.C., Correa, P., Pedroso, A.M. \& Santos, F.A.P., 2015. Starch levels on performance, milk composition and energy balance of lactating dairy cows. Trop. Anim. Health Prod. 47, 179184.

Cavestany, D., Viñoles, C., Crowe, M.A., La Manna, A. \& Mendoza, A., 2009b. Effect of prepartum diet on postpartum ovarian activity in Holstein cows in a pasture-based dairy system. Anim. Reprod. Sci. 114, 1-13.

Cavestany, D., Kulcsár, M., Crespi, D., Chilliard, Y., La Manna, A., Balogh, O., Keresztes, M., Delavaud, C., Huszenicza, G. \& Meikle, A., 2009a. Effect of prepartum energetic supplementation on productive and reproductive characteristics and metabolic and hormonal profiles in dairy cows under grazing conditions. Reprod. Domest. Anim. 44, 663-671.

Chagas, L.M., Bass, J.J., Blache, D., Burke, C.R., Kay, J.K., Lindsay, D.R., Lucy, M.C., Martin, G.B., Meier, S., Rhodes, F.M., Roche, J.R., Thatcher, W.W. \& Webb, R., 2007. Invited review: New perspectives on the roles of nutrition and metabolic priorities in the subfertility of high-producing dairy cows. J. Dairy Sci. 90, 4022-4032.

Chalupa, W.B., Vecchiarelli, B., Elser, A.E. \& Kronfeld, D.S., 1986. Ruminal fermentation in vivo as influenced by longchain fatty acids. J. Diary Sci. 69, 1293-1301.

Chouinard, P.Y., Girard, V. \& Brisson, G.J., 1997. Lactational response of cows to different concentrations of calcium salts of canola oil fatty acids with or without bicarbonates. J. Dairy Sci. 80, 1185-1193.

Damgaard, D.M, Weisbjerg, M.R. \& Larsen, T., 2013. Priming the cow lactation by rapeseed supplementation in the dry period. J. Dairy Sci. 96, 3652-3661.

Dann, H.M., Varga, G.A. \& Putman, D.E., 1999. Improving energy supply to late gestation and early postpartum dairy cows. J. Dairy Sci. 82, 1765-1778.

Dann, H.M., Morin, D.E., Bollero, G.A., Murphy, M.R. \& Drackley, J.K., 2005. Prepartum intake, postpartum induction of ketosis and periparturient disorders affect the metabolic status of dairy cows. J. Dairy Sci. 88, 3249-3264.

Diskin, M.G., Mackey, D.R., Roche, J.F. \& Sreenan, J.M., 2003. Effects of nutrition and metabolic status on circulating hormones and ovarian follicle development in cattle. Anim. Reprod. Sci. 78, 345-370.

Doreau, M. \& Ferlay, A., 1994. Digestion and utilisation of fatty acids by ruminants. Anim. Feed Sci. Technol., 45, 379396.

Drackley, J.K., 1999. Biology of dairy cows during the transition period: The final frontier? J. Dairy Sci. 82, $2259-2273$.

Drackley, J.K., 2000. Lipid metabolism. In: J.P.F. D'Mello (ed). Farm animal metabolism and nutrition. CABI, London, pp. 97-119.

Drackley, J.K., Overton, T.R. \& Douglas, G.N., 2001. Adaptations of glucose and long-chain fatty acid metabolism in liver of dairy cows during the periparturient period. J. Dairy Sci. 84, E100-E112.

Drackley, J.K., Dann, H.M., Douglas, G.N., Janovick, N.A., Litherland, N.B., Underwood, J.P. \& Loor, J.J., 2005. Physiological and pathological adaptations in dairy cows that may increase susceptibility to periparturient disease and disorders. Ital. J. Anim. Sci. 4, 323-344.

Drehmann, P.C., 2000. Should we rethink our close-up rations? Hoard's Dairyman 145, 641.

Duffield, T.F., 2000. Subclinical ketosis in lactating dairy cattle. Met. Disord. Rum. 16, 231-253.

Duffield, T.F., Lissemore, K.D., McBride, B.W. \& Leslie, K.E., 2009. Impact of hyperketonemia in early lactation dairy cows on health and production. J. Dairy Sci. 92, 571-580.

Dyck, B.L., Colazo, M.G., Ambrose, D.J., Dyck, M.K. \& Doepel, L., 2011. Starch source and content in postpartum dairy cow diets: Effects on plasma metabolites and reproductive processes. J. Dairy Sci. 94, 4636-4646.

Erickson, P.S., Murphy, M.R. \& Clark, J.H., 1992. Supplementation of dairy cow diets with calcium salts of long-chain fatty acids and nicotinic acid in early lactation. J. Dairy Sci. 75, 1078-1089.

Esposito, G., Irons, P.C., Webb, E.C. \& Chapwanya, A., 2014. Interactions between negative energy balance, metabolic diseases, uterine health and immune response in transition dairy cows. Anim. Reprod. Sci.144, 60-71.

Esposito G., Absalôn, M.V.A., Schneider, A., Gilbert, R.O. \& Butler, W.R., 2012. Effect of dietary conjugated linoleic acid on metabolism and reproduction in dairy cows. S. Afr. J. Anim. Sci. 30, 33-37.

Evans, A.C.O. \& Walsh, S.W., 2012. The physiology of multifactorial problems limiting the establishment of pregnancy in dairy cattle. Reprod. Fertil. Dev. 24, 233-237.

Everitt, G.C., 1964. Maternal undernutrition and retarded foetal development in Merino sheep. Nature 201, 1341 -1342.

Forde, N. Beltman, M.E., Lonergan, P. Diskin, M., Roche, J.F. \& Crowe, M.A., 2011. Oestrous cycles in Bos Taurus cattle. Anim. Reprod. Sci. 124, 163-169.

Friggens, N.C., 2003. Body lipid reserves and the reproductive cycle: Towards a better understanding. Livest. Prod. Sci. 82, 219-236. 
Gama, M.A.S., Garnsworthy, P.C., Griinari, J.M., Leme, P.R., Rodrigues, P.H.M., Souza, L.W.O. \& Lanna, D.P.D., 2008. Diet-induced milk fat depression: Association with changes in milk fatty acid composition and fluidity of milk fat. Livest. Sci. 115, 319-331.

Garcia-Bojalil, C.M., Staples, C.R., Risco, C.A., Savio, J.D. \& Thatcher, W.W., 1998. Protein degradability and calcium salts of long-chain fatty acids in the diets of lactating dairy cows: Reproductive responses. J. Dairy Sci. 81, 13851395.

Garnsworthy, P.C. \& Webb, R., 1999. The influence of nutrition on fertility in dairy cows. In: P.C. Garnsworthy \& J. Wiseman (eds). Recent advances in animal nutrition. Nottingham University Press, pp. 39-57.

Garnsworthy, P.C., Sinclair, K.D. \& Webb, R., 2008a. Integration of physiological mechanisms that influence fertility in dairy cows. Animal 2, 1144-1152.

Garnsworthy, P.C., Fouladi-Nashta, A.A., Mann, G.E., Sinclair, K.D. \& Webb, R., 2009. Effect of dietary-induced changes in plasma insulin concentrations during the early postpartum period on pregnancy rate in dairy cows. Reprod. 137, 759-768.

Garnsworthy, P.C., Lock, A., Mann, G.E., Sinclair, K.D. \& Webb, R., 2008b. Nutrition, metabolism and fertility in dairy cows: 1. Dietary energy source and ovarian function. J. Dairy Sci. 91, 3814-3823.

Garnsworthy, P.C., Lock, A., Mann, G.E., Sinclair, K.D. \& Webb, R., 2008c. Nutrition, metabolism and fertility in dairy cows: 2. Dietary fat content and ovarian function. J. Dairy Sci. 91, 3824-3833.

Gilmore, H.S., Young, F.J., Patterson, D.C., Wylie, A.R.G., Law, R.A., Kilpatrick, D.J., Elliot, C.T. \& Mayne, C.S., 2011. An evaluation of the effect of altering nutrition and nutritional strategies in early lactation on reproductive performance and oestrous behaviour of high yielding Holstein Friesian dairy cows. J. Dairy Sci. 94, 3510-3526.

Giuliodori, M.J., Delavaud, C., Chilliard, Y., Becú-Villalobos, D., Lacau-Mengido, I. \& De la Sota, R.L., 2011. High NEFA concentrations around parturition are associated with delayed ovulations in grazing dairy cows. Livest. Sci. 141, 123-128.

Goff, J.P., 2006. Major advances in our understanding of nutritional influences on bovine health. J. Dairy Sci. 89, $1292-$ 1301.

Gong, J.G., Lee, W.J., Garnsworthy, P.C. \& Webb, R., 2002. Effect of dietary-induced increases in circulating insulin concentrations during the early postpartum period on reproductive function in dairy cows. Reprod. 123, 419-427.

Gröhn, Y.T., Eicker, S.W. \& Hertl, J.A., 1995. The association between previous 305-day milk yield and disease in New York State dairy cows. J. Dairy Sci. 78, 1693-1702.

Gröhn, Y.T., Eicker, S.W., Ducrocq, V. \& Hertl, J.A., 1998. Effect of diseases on the culling of Holstein dairy cows in New York State. J. Dairy Sci. 81, 966-978.

Grum, D.E., Drackley, J.K., Younker, R.S., LaCount, D.W. \& Veenhuizen, J.J., 1996. Nutrition during the dry period and hepatic lipid metabolism of periparturient dairy cows. J. Dairy Sci. 79, 1850-1864.

Grummer, R.R., 1995. Impact of changes in organic nutrient metabolism on feeding the transition dairy cow. J. Anim. Sci. $73,2820-2833$.

Hansen, P.J., Soto, P. \& Natzke, R.P., 2004. Mastitis and fertility in cattle: Possible involvement of inflammation or immune activation in embryonic mortality. Am. J. Reprod. Immunol. 51, 294-301.

Harrison, J.H., Kincaid, R.L., McNamara, J.P., Waltner, S., Loney, K.A., Riley, R.E. \& Cronrath, J.D., 1995. Effect of whole cottonseeds and calcium salts of long-chain fatty acids on performance of lactating dairy cows. J. Dairy Sci. 78, 181-193.

Hermansen, J.E., 1990. Food intake, milk yield and live weight gain of dairy cows given increased amounts of calciumsaponified fatty acids of palm acid oil. Anim. Prod. 50, 11-18.

Higgs, R.J., Sheahan, A. J., Mandok, K., Van Amburgh, M.E. \& Roche, J.R., 2013. The effect of starch-, fiber-, or sugarbased supplements on nitrogen utilization in grazing dairy cows. J. Dairy Sci.96, 3857-3866.

Hills, J.L., Wales, W.J., Dunshea, F.R., Garcia, S.C. \& Roche, J.R., 2015. Invited review: An evaluation of the likely effects of individualized feeding of concentrate supplements to pasture-based dairy cows J. Dairy Sci. 98, 13631401.

Holter, J.B. \& Young, A.J., 1992. Methane prediction in dry and lactating Holstein cows. J. Dairy Sci. 75, $2165-2175$.

Huzzey, J.M., Veira, D.M., Weary, D.M. \& Von Keyserlingk, M.A.G., 2007. Prepartum behaviour and dry matter intake identify dairy cows at risk for metritis. J. Dairy Sci. 90, 3220-3233.

Ingvartsen, K.L., 2006. Feeding- and management-related diseases in the transition cow: Physiological adaptations around calving and strategies to reduce feeding-related diseases. Anim. Feed Sci. Technol. 126, 175-213.

Ingvartsen, K.L. \& Andersen, J.B., 2000. Integration of metabolism and intake regulation: A review focusing on periparturient animals. J. Dairy Sci. 83, 1573-1597.

Janovick, N.A., Boisclair, Y.R. \& Drackley, J.K., 2011. Prepartum dietary energy intake affects metabolism and health during the periparturient period in primiparous and multiparous Holstein cows J. Dairy Sci. 94, 1385-1400.

Janovick, N.A. \& Drackley, J.K., 2010. Prepartum dietary management of energy intake affects postpartum intake and lactation performance by primiparous and multiparous Holstein cows. J. Dairy Sci. 93, 3086-3102.

Jordan, E.R. \& Fourdraine, R.H., 1993. Characterization of the management practices of the top milk producing herds in the country. J. Dairy Sci. 76, 3247-3256.

Jorritsma, R., Wensing, T., Kruip, T.A., Vos, P.L. \& Noordhuizen, J.P., 2003. Metabolic changes in early lactation and impaired reproductive performance in dairy cows. Vet. Res. 34, 11-26.

Jouany, J.P., 2006. Optimizing rumen functions in the close-up transition period and early lactation to drive dry matter intake and energy balance in cows. Anim. Reprod. Sci. 96, 250-264. 
Kalscheur, K.F., Teter, B.B., Piperova, L.S. \& Erdman, R.A., 1997. Effect of dietary forage concentrate and buffer addition on duodenal flows of trans-C18:1 fatty acids and milk fat production in dairy cows. J. Dairy Sci. 80, 21042114.

Lammoglia, M.A., Willard, S.T., Hallford, D.M. \& Randel, R.D., 1997. Effect of dietary fat on follicular development and circulating concentrations of lipids and insulin on follicular development and circulating concentrations of lipids, insulin, progesterone, oestradiol $17 \beta, 13,14$-dihydro-15-keto-prostaglandin $F_{2 \alpha}$ and growth hormone in oestrous cyclic Brahman cows. J. Anim. Sci. 75, 1591-1600.

Lammoglia, M.A., Willard, S.T., Oldham, J.R. \& Randel, R.D., 1996. Effects of dietary fat and season on steroid hormonal profiles before parturition and on hormonal, cholesterol, triglycerides, follicular patterns and postpartum reproduction in Brahman cows. J. Anim. Sci. 74, 2253-2262.

LeBlanc, S.J., Duffield, T.F., Leslie, K.E., Bateman, K.G., Keefe, G.P., Walton, J.S. \& Johnson, W.H., 2002. The effect of treatment of clinical endometritis on reproductive performance in dairy cows. J. Dairy Sci. 85, 2237-2249.

Leroy, J.L.M.R., Sturmey, R.G., Van Hoeck, V., De Bie, J., McKeegan, P.J. \& Bols, P.E.J., 2014. Dietary fat supplementation and the consequences for oocyte and embryo quality: Hype or significant benefit for dairy cow reproduction? Reprod. Dom. Anim. 49, 353-361.

Leroy, J.L.M.R., Vanholder, T., Van Knegsel, A.T.M., Garcia-Ispierto, I. \& Bols, P.E.J., 2008a. Nutrient prioritization in dairy cows early postpartum: Mismatch between metabolism and fertility? Reprod. Dom. Anim. 43, 96-103.

Leroy, J.L.M.R., Opsomer, G., Van Soom, A., Goovaerts, I.G.F. \& Bols, P.E.J., 2008b. Reduced fertility in high-yielding dairy cows: Are the oocyte and embryo in danger? Part I The importance of negative energy balance and altered corpus luteum function to the reduction of oocyte and embryo quality in high-yielding dairy cows. Reprod. Domest. Anim. 43, 612-622.

Leroy, J.L.M.R., Van Soom, A., Opsomer, G., Goovaerts, I.G.F \& Bols, P.E.J., 2008c. Reduced fertility in high-yielding dairy cows: Are the oocyte and embryo in Danger? Part II Mechanisms linking nutrition and reduced oocyte and embryo quality in high-yielding dairy cows. Reprod. Dom. Anim. 43, 623-632.

Little, M.W., O'Connell, N.E. \& Ferris, C.P., 2016. A comparison of individual cow versus group concentrate allocation strategies on dry matter intake, milk production, tissue changes and fertility of Holstein-Friesian cows offered a grass silage diet. J. Dairy Sci. 99, 4360-4373.

Lock, A.L. \& Bauman, D.E., 2004. Modifying milk fat composition of dairy cows to enhance fatty acids beneficial to human health. Lipids 39, 1197-1206.

Lucy, M.C., 2001. Reproductive loss in high-producing dairy cattle: Where will it end? J. Dairy Sci. 84, 1277-1293.

Lucy, M.C., 2003. Mechanisms linking nutrition and reproduction in postpartum cows. Reprod. Suppl. 61, 415-427.

Lucy, M.C., 2004. Mechanisms linking the somatotropic axis with insulin: Lessons from the postpartum dairy cow, Proc. NZ Soc. Anim. Prod. 64: 19-24.

Lucy, M.C., 2007. Fertility in high-producing dairy cows: Reasons for decline and corrective strategies for sustainable improvement. Soc. Reprod. Fertil. Suppl. 64, 237-254.

Lucy, M.C., Staples, C.R., Michel, F.M., Thatcher, W.W. \& Bolt, D.J., 1991. Effect of feeding calcium soaps to early postpartum dairy cows on plasma prostaglandin- $F_{2 a}$, luteinizing hormone and follicular growth. J. Dairy Sci. 74 , 483-489.

Makgahlela, L., 2008. National milk recording scheme. Newsletter \# 13, pp. 20.

Mallard, B.A., Dekkers, J.C., Ireland, M.J., Leslie, K.E., Sharif, S., Vankampen, C.L., Wagter, L. \& Wilkie, B.N., 1998. Alteration in immune responsiveness during the peripartum period and its ramification on dairy cow and calf health. J. Dairy Sci. 81, 585-595.

Mann, S., Leal Yepes, F.A., Overton, T.R., Wakshlag, J.J., Lock A.L., Ryan, C.M. \& Nydam, D.V., 2015. Dry period plane of energy: Effects on feed intake, energy balance, milk production and composition in transition dairy cows. J. Dairy Sci. 98, 3366-3382.

McArt, J.A., Nydam, D.V. \& Oetzel, R., 2012. A field trial on the effect of propylene glycol on displaced abomasum, removal from herd and reproduction in fresh cows diagnosed with subclinical ketosis. J. Dairy Sci. 95, 2505-2512.

McArt, J.A., Nydam, D.V, Oetzel, G.R., Overton, T.R. \& Ospina, P.A., 2013. Elevated non-esterified fatty acids and $\beta$ hydroxybutyrate and their association with transition dairy cow performance. Vet. J. 198, 560-570.

McDonald, P., Edwards, R., Greenhalgh, J.F.D. \& Morgan, C.A., 2002. Animal nutrition. 6th edition. Harlow, Pearson Education, Prentice Hall, England.

McGuire, M.A., Griinari, J.M., Dwyer, D.A. \& Bauman, D.E., 1995. Role of insulin in the regulation of mammary synthesis of fat and protein. J. Dairy Sci. 78, 816-824.

McGuire, M.A., Theurer, M., Vicini, J.L. \& Crooker, B., 2004. Controlling energy balance in early lactation. Adv. Dairy Technol. 16, 214-252.

McNamara, S., Murphy, J.J., Rath, M. \& O’Mara, F.P., 2003. Effects of different transition diets on energy balance, blood metabolites and reproductive performance in dairy cows. Livest. Prod. Sci. 84, 195-206.

Minor, D.J., Trower, S.L., Strang, B.D., Shaver, R.D. \& Grummer, R.R., 1998. Effects of non-fibre carbohydrate and niacin on periparturient metabolic status and lactation of dairy cows. J. Dairy Sci. 81,189-200.

Moallem, U., Folman, Y. \& Sklan, D., 2000. Effects of somatotropin and dietary calcium soaps of fatty acids in early lactation on milk production, dry matter intake and energy balance of high-yielding dairy cows. J. Dairy Sci. 83, 2085-2094

Moallem, U., Katz, M., Arieli, A. \& Lehrer, H., 2007. Effects of peripartum propylene glycol or fats differing in fatty acid profiles on feed intake, production and plasma metabolites in dairy cows. J. Dairy Sci. 90, 3846-3856.

Mosavi, G.R., Fatahnia, F., Alamouti, H.R.M., Mehrabi, A.A. \& Kohi, H.D., 2012. Effect of dietary starch source on milk production and composition of lactating Holstein cows. S. Afr. J. Anim. Sci. 42, 201-209. 
Mwaanga, E.S. \& Janowski, T., 2000. Anoestrus in Dairy Cows: Causes, prevalence and clinical forms. Reprod. Dom. Anim. 35, 193-200.

National Research Council (NRC), 2001. Nutrient requirements of dairy cattle. 7th rev. ed. National Academy Press, Washington, DC, USA.

Norberg, E., Volden, H. \& Harstad, O.M., 2007. Technical note: Assessment of recovery site of mobile nylon bags for measuring ileal digestibility of starch in dairy cows. J. Dairy Sci. 90, 418-421.

Oldick, B.S., Staples, C.R., Thatcher, W.W. \& Gyawu, P., 1997. Abomasal infusion of glucose and fat effect on digestion, production and ovarian and uterine functions of cows. J. Dairy Sci. 80, 1315-1328.

Olsson, G., Emanuelson, M. \& Wiktorsson, H., 1998. Effects of different nutritional levels prepartum on the subsequent performance of dairy cows. Livest. Prod. Sci. 53, 279-290.

Ospina, P.A., Nydam, D.V., Stokol, T. \& Overton, T.R., 2010a. Evaluation of non-esterified fatty acids and betahydroxybutyrate in transition dairy cattle in the north eastern United States: Critical thresholds for prediction of clinical diseases. J. Dairy Sci. 93, 546-554.

Ospina, P.A., Nydam, D.V., Stokol, T. \& Overton, T.R., 2010b. Associations of elevated non-esterified fatty acids and beta-hydroxybutyrate concentrations with early lactation reproductive performance and milk production in transition dairy cattle in the north eastern United States. J. Dairy Sci. 93, 1596-1603.

Ospina, P.A., Nydam, D.V., Stokol, T. \& Overton, T.R., 2010c. Association between the proportion of sampled transition cows with increased non-esterified fatty acids and beta-hydroxybutyrate and disease incidence, pregnancy rate and milk production at the herd level. J. Dairy Sci. 93, 3595-3601.

Palmquist, D.L., 1988. The feeding value of fat. In: Feed science. E.R. Ørskov (ed).Elsevier, Amsterdam, Netherlands, pp. 293-311.

Palmquist, D.L., 1994. The role of dietary fats in efficiency of ruminants. J. Nutr. 124, 1377S-1382S.

Piccioli-Cappelli, F., Loor, J.J., Seal, C.J. Minuti, A. \& Trevisi, E., 2014. Effect of dietary starch level and high rumenundegradable protein on endocrine-metabolic status, milk yield and milk composition in dairy cows during early and late lactation. J. Dairy Sci. 97, 7788-7803.

Purushothaman, S., Kumar, A.\&Tiwari, D.P., 2008. Effect of feeding calcium salts of palm oil fatty acids on performance of lactating crossbred cows. Asian-Aust. J. Anim. Sci. 21, 376-385.

Pyörälä, S., 2008. Mastitis in postpartum dairy cows. Reprod. Domest. Anim. 43, 252-259.

Rabelo, E., Rezende, R.L., Bertics, S.J. \& Grummer, 2005. Effects of prepartum and postfresh transition diets varying in dietary energy density on metabolic status of periparturient dairy cows. J. Dairy Sci. 88, 4375-4383.

Rajala-Schultz, P.J., Gröhn, Y.T. \& McCulloch, C.E., 1999a. Effects of milk fever, ketosis and lameness on milk yield in dairy cows. J. Dairy Sci. 82, 288-294.

Rajala-Schultz, P.J., Gröhn, Y.T. McCulloch, C.E. \& Guard, C.L., 1999b. Effects of clinical mastitis on milk yield in dairy cows. J. Dairy Sci. 82, 1213-1220.

Rearte, D.H. \& Pieroni, G.A., 2001. Supplementation of temperate pasture. Proc. 19th Intern. Grassl. Cong., pp. 679689.

Reis, M.M., Cooke, R.F, Ranches, J. \& Vasconcelos, J.L.M., 2012. Effects of calcium salts of polyunsaturated fatty acids on productiveand reproductive parameters of lactating Holstein cows. J. Dairy Sci. 95, 7039-7050.

Roche, J.R., Burke, C.R., Meier, S. \& Walker, C.G., 2011. Nutrition x reproduction interaction in pasture-based systems: Is nutrition a factor in reproductive failure? Anim. Prod. Sci. 51, 1045-1066.

Roche, J.R., Kay, J.K., Rius, A.G., Grala, T.M., Sheahan, A.J., White, H.M. \& Phyn, C.V.C., 2013. Short communication: Immediate and deferred milk production responses to concentrate supplements in cows grazing fresh pasture. J. Dairy Sci. 96, 2544-2550.

Roche, J.R., Friggens, N.C., Kay, J.K., Fisher, M.W., Stafford, K.J. \& Berry, D.P., 2009. Invited review: Body condition score and its association with dairy cow productivity, health and welfare. J. Dairy Sci. 92, 5769-5801.

Rukkwamsuk, T., Kruip, T.A. Meijer, G.A. \& Wensing, T., 1999. Hepatic fatty acid composition in periparturient dairy cows with fatty liver induced by intake of a high energy diet in the dry period. J. Dairy Sci. 82, 280-287.

Ryan, D.P., Spoon, R.A. \& Williams, G.L., 1992. Ovarian follicular characteristics, embryo recovery and embryo viability in heifers fed high-fat diets and treated with follicle- stimulating-hormone. J. Anim. Sci. 70, 3505-3513.

Santos, J.E.P., Bilby, T.R., Thatcher, W.W., Staples, C.R. \& Silvestre, F.T., 2008. Long chain fatty acids of diet as factors influencing reproduction in cattle. Reprod. Dom. Anim. 43, 23-30.

Schneider, P., Sklan, I.D., Chalupa, W. \& Kronfeld, D.S., 1988. Feeding calcium salts of fatty acids to lactating cows. J. Dairy Sci. 71, 2143-2150.

Schulz, K., Frahm, J., Meyer, U., Kersten, S., Reiche, D., Rehage, J. \& Dänicke, S., 2014. Effects of prepartal body condition score and peripartal energy supply of dairy cows on postpartal lipolysis, energy balance and ketogenesis: An animal model to investigate subclinical ketosis. J. Dairy Res. 81, 257-266.

Schroeder, G.F., Gagliostro, G.A., Bargo, F., Delahoy, J.E. \& Muller, L.D., 2004. Effects of fat supplementation on milk production and composition by dairy cows on pasture: A review. Livest. Prod. Sci. 86, 1-18.

Seifi, H.A., LeBlanc, S.J., Leslie, K.E. \& Duffield, T.F., 2011. Metabolic predictors of postpartum disease and culling risk in dairy cattle. Vet. J. 188, 216-220.

Staples, C.R. \& Thatcher, W.W., 2005. Effect of fatty acids on reproduction of dairy cows. In: Recent advances in animal nutrition. Ed. Garnsworthy, P.C. \& Wiseman, J., Nottingham university press, pp. 229-259.

Staples, C.R., Burke, J.M. \& Thatcher, W.W., 1998. Influence of supplemental fats on reproductive tissues and performance of lactating cows. J. Dairy Sci. 81, 856-871.

Steyn, L. Meeske, R. \& Cruywagen, C.W., 2017. Replacing maize grain with dried citrus pulp in a concentrate feed for Jersey cows grazing ryegrass pasture. S. Afr. J. Anim. Sci. 47, 553-564. 
Thatcher, W.W., 2017. A 100-year review: Historical development of female reproductive physiology in dairy cattle. J. Dairy Sci. 100, 10272-10291.

Thatcher, W.W., Santos, J.E.P. \& Staples, C.R., 2011. Dietary manipulations to improve embryonic survival in cattle. Theriogenology 76, 1619-1631.

Thatcher, W.W., Santos, J.E.P., Silvestre, F.T., Kim, I.H. \& Staples, C.R., 2010. Perspective on physiological/endocrine and nutritional factors influencing fertility in postpartum dairy cows. Reprod. Dom. Anim. 45, 2-14.

Van Knegsel, A.T.M., Van den Brand, H., Dijkstra, J., Van Straalen, W.M., Heetkamp, M.J.W., Tamminga, S. \& Kemp, B., 2007a. Dietary energy source in dairy cows in early lactation: Energy partitioning and milk composition. J. Dairy Sci. 90, 1467-1476.

Van Knegsel, A.T.M., Van den Brand, H., Graat, E.A.M., Dijkstra, J., Jorritsma, R., Decuypere, E., Tamminga, S. \& Kemp, B., 2007b. Dietary energy source in dairy cows in early lactation: Metabolites and metabolic hormones. J. Dairy Sci. 90, 1477-1485.

Van Knegsel, A.T.M., Van den Brand, H., Dijkstra, J., Van Straalen, W.M., Jorritsma, R., Tamminga, S. \& Kemp, B., 2007c. Effect of glucogenic vs lipogenic diets on energy balance, blood metabolites and reproduction in primiparous and multiparous dairy cows in early lactation. J. Dairy Sci. 90, 3397-3409.

Van Knegsel, A.T.M., Van den Brand, H., Dijkstra, J. \& Kemp, B., 2007d. Effects of dietary energy source on energy balance, metabolites and reproduction variables in dairy cows in early lactation. Theriogenology 68S, S274-S280.

Van Knegsel, A.T.M., Van den Brand, H., Dijkstra, J., Van Straalen, W.M., Jorritsma, R., Tamminga, S. \& Kemp, B., 2005. Effect of dietary energy source on energy balance, production, metabolic disorders and reproduction in lactating dairy cattle. Reprod. Nutr. Dev. 45, 665-688.

Van Straten, M., Shpigel, N.Y. \& Friger, M., 2008. Analysis of daily body weight of high-producing dairy cows in the first one hundred twenty days of lactation and associations with ovarian inactivity. J. Dairy Sci. 91, 3353-3362.

Vasconcelos, J.L.M., Sartori, R., Oliveira, H.N., Guenther, J.G. \& Wiltbank, M.C., 2001. Reduction in size of the ovulatory follicle reduces subsequent luteal size and pregnancy rate. Theriogenology 56, 307-314.

Vernon, R.G., 2002. Nutrient partitioning, lipid metabolism and relevant imbalances. Proceedings of the 12th World Buiatrics Congress, Hannover, Germany, 18-23 August, 2002.

Vickers, L.A., Weary, D.M., Veira, D.M. \& Von Keyserlingk, M.A., 2013. Feeding a higher forage diet prepartum decreases incidences of subclinical ketosis in transition dairy cows. J. Anim. Sci. 91, 886-894.

Voigt, J., Gaafar, K., Hagemeister, H., Kanitz, W. \& Precht, D., 2003. Fat vs starch as energy sources in diets for high yielding lactating dairy cows. In: Progress in research on energy and protein metabolism, Rostock, Germany, pp. 445-448.

Walsh, S.W., Williams, E.J. \& Evans, A.C.O., 2011. A review of the causes of poor fertility in high milk producing dairy cows. Anim. Reprod. Sci. 123,127-138.

Wankhade, P.R., Manimaran, A., Kumaresan, A., Jeyakumar, S., Ramesha, K.P., Sejian, V., Rajendran, D. \& Varghese, M.R., 2017. Metabolic and immunological changes in transition dairy cows: A review. Vet. World 10, 1367-1377.

Wathes, D.C., 2012. Mechanisms linking metabolic status and disease with reproductive outcome in the dairy cow. Reprod. Dom. Anim. 47, 304-312.

Wathes, D.C, Abayasekara, D.R.E. \& Aitken, R.J., 2007. Polyunsaturated fatty acids in male and female reproduction. Biol. Reprod. 77, 190-201.

Wathes, D.C., Cheng, Z., Chowdhury, W., Fenwick, M.A., Fitzpatrick, R., Morris, D.G., Patton, J. \& Murphy, J.J., 2009. Negative energy balance alters global gene expression and immune responses in the uterus of postpartum dairy cows. Physiol. Genomics 39, 1-13.

Webb, R., Garnsworthy, P.C., Gong, J.G. \& Armstrong, D.G., 2004. Control of follicular growth: Local interactions and nutritional influences. J. Anim. Sci. 82, E63-E74.

Williams, G.L. \& Stanko, R.L., 2000. Dietary fats as reproductive nutraceuticals in beef cattle. J. Anim. Sci. 77, E1-E12. 